\title{
CHALLENGE AND CHANGE IN SCHOLASTIC JOURNALISM AS RELATED TO THE TEACHING AND LEARNING OF ENGLISH LANGUAGE ARTS
}

\section{Stacy Haynes-Moore ${ }^{1}$}

\begin{abstract}
Changing notions of 'literacy' impact and complicate ways in which English language arts educators adapt curriculum in meaningful ways for students. In this paper, I position scholastic journalism as authentic, $21^{\text {st }}$ century ELA coursework. I provide an historical overview of scholastic journalism. I emphasize impacts of media law, emergent technologies, and redesigned school literacy goals to the ways in which scholastic journalism negotiates acceptance within ELA curriculum.
\end{abstract}

Key words: scholastic journalism, new literacies, English language arts electives, student publications, media curriculum

It is a wintery Saturday morning and a small group of student writers and editors wait outside Publications Room 70 eager for me to unlock the school door. The group is ready to work. They

\footnotetext{
${ }^{1}$ Stacy Haynes-Moore < stacy-haynesmoore@uiowa.edu> +13195584581 is a Ph.D. student at the University of Iowa College of Education, Office of Teaching and Learning, Language, Literacy and Culture, Iowa City, IA 52242-5500, U.S.A. She is also a language arts teacher at Kennedy High School, Cedar Rapids, Iowa 52402-2212.
} 
arrived at school promptly at 8 a.m., anxious to begin the proofreading, editing, and final design touches to their student newsmagazine that must be electronically transmitted by noon to the newspaper publisher. This production routine occurs nine times a year, with the Saturday session marking the culmination of work by the Student Editorial Board. During the school day, the SEB leads their classmates to establish goals and mini-deadlines for the monthly publication cycle. Lively discussion ensues with the story brainstorming session, which usually spills into two or three days of students' classes. They pitch and argue angles until editors prioritize the line-up of school news, features, sports, and editorials.

As their faculty adviser, I am not asked or required to approve their decisions; I am a certified journalism educator and adhere to the principles of scholastic journalism. Expectations are to provide them instruction, communicate media trends, guide students' use of technology, develop editorial leaders, and advise students on issues of media law and ethics (Downes, Hayes, Furnas, and Newton 2012, Journalism Education Association, 2013). High school media teach students about access of information in a democracy; sharpen students' writing, research, and language; and ask students to engage in a collaborative production (Dvorak, Lain, and Dickson 1994). Scholastic journalism is hands-on studentcentered learning.

\section{CHANGING NOTIONS OF STUDENT LITERACIES}

What scholastic journalism means and what it encompasses today is dynamic (Brasler and Aimone 2010, Haynes-Moore 2011a, Pell 2012). Program directions reflect society's broadened notions of literacy and learning (Gee and Hayes 2011, Hull and Moje 2012, Ito et al. 2008, Lankshear 
and Knobel 2006). Twenty-first century literacies invite classroom teaching to embrace practices that are social, collaborative, and continuously evolving (Gee and Hayes, 2011, Ito et al. 2008).

Literacy involves people in participation, relationships, and interactions (Jenkins, Purushotma, Clinton, Weigel, and Robison 2007, Luke and Moje 2009). Today's students harness new technologies that extend the ways in which we learn and communicate (Buckingham 2011, Halverson and Shapiro 2012, Herrington, Hodgson and Moran 2009, Ito et al. 2008, Jenkins, Purushotma, Clinton, Weigel, and Robison 2007, Lankshear and Knobel 2006, New London Group 1996, Newkirk and Kent 2007). Journalism classrooms illustrate such ideas of $21^{\text {st }}$ century learning.

Student production processes prove to be as valuable as the final results. With each monthly production cycle, editors consult with peers and address concerns about writing and storytelling. Designers build visual mock-ups. Reporters revise copy. Web reporters churn out timely stories for the school audience. Photographers capture sports and fine arts activities. A business manager makes sales calls. A social media manager writes tweets. Page editors hold design meetings. Subscriptions personnel organize spreadsheets for the mailing system. Organizational leaders- the student editorial board - charge ahead toward deadline, though they may feel weary managing their team and finding solutions to last-minute problems. There emerges in this process a shared sense of engagement. Journalism students learn and work together to produce a product. 
136 Celt, Volume 13, Number 2, December 2013:133-154

\section{OVERVIEW OF THE CURRENT STATE OF HIGH SCHOOL JOURNALISM}

Scholastic journalism programs are closely connected with English language arts (Applebee 1974, Dvorak 1985, 2006, NCTE 2012). Program goals directly tie to standards of school literacy curriculum, aiming to foster students' abilities to write, respond, discuss, and use technologies in languagerich practices (Common Core State Standards Initiative 2012; DeVoss, Eidman-Adahl, and Hicks 2010, Hull Moje 2012). Working on a school publication is "authentic measurement at best: a synthesis of analysis and critical thinking, planning and relating to audience beyond the classroom, and performancebased outcomes" (Graff 2003). The International Reading Association, National Council of Teachers of English, and Common Core State Standards guide academic expectations of English curriculum. In 2002, the NCTE and IRA encouraged integrating journalism curriculum with English classrooms. Overall, scholastic journalism maintains a foothold (Dvorak 1998, 2002, 2008, Goodman, Bowen, and Bobkowski 2011). Kent State Center for Scholastic Journalism reports that 96 percent of U.S. public high schools offer student media programs and student newspapers operate in 64 percent of the nation's public high schools (Goodman, Bowen, and Bobkowski 2011).

Networks for training and support are available from state, regional, and national organizations, including the Journalism Education Association, Quill and Scroll, Student Press Law Center, Columbia Scholastic Press Association, and National Scholastic Press Association (Columbia Scholastic Press Association 1998). These organizations frame the standards for scholastic journalism (Downes, Hayes, Furnas, and Newton 2012). Currently, the Common Core Standards 
Initiative (2012) supplements literacy goals already established by the NCTE and IRA. The Common Core describes aims of English language arts as developing and broadening student literacies in ways that prepare students for college and the workplace. This framework includes reading, writing, speaking, listening, language, media, and technology. As illustrated in Figure 1, student experiences in scholastic journalism can be mapped to desired core literacy goals.

\begin{tabular}{|l|l|}
\hline \multicolumn{1}{|c|}{$\begin{array}{c}\text { Common Core } \\
\text { Standard (2012) }\end{array}$} & Scholastic Journalism Practice \\
\hline $\begin{array}{l}\text { Reading: Students should read a } \\
\text { diverse array of texts in a range } \\
\text { of subjects. Students are expected } \\
\text { to build knowledge, gain insights, } \\
\text { explore possibilities, and broaden } \\
\text { their perspective. }\end{array}$ & $\begin{array}{l}\text { Students read national and local } \\
\text { texts such as books, essays, } \\
\text { columns, and online articles to build } \\
\text { knowledge about issues and } \\
\text { perspectives. Example: Student } \\
\text { reporter writing about gun control } \\
\text { reads a variety of texts to better } \\
\text { understand the issue and } \\
\text { controversies surrounding this topic. }\end{array}$ \\
\hline $\begin{array}{l}\text { Writing: Students should write } \\
\text { with logical arguments based on } \\
\text { substantive claims, sound } \\
\text { reasoning, and relevant evidence } \\
\text { is a cornerstone of the writing } \\
\text { standards, with opinion writing. } \\
\text { Research is emphasized. }\end{array}$ & $\begin{array}{l}\text { Students write editorial, opinion, } \\
\text { and review stories, making claims } \\
\text { based on fact and research, using } \\
\text { evidence in writing. }\end{array}$ \\
$\begin{array}{l}\text { Example: Student reporter argues } \\
\text { for healthier cafeteria foods, using } \\
\text { evidence from a variety of text and } \\
\text { people sources to substantiate her } \\
\text { claims. }\end{array}$ \\
\hline $\begin{array}{l}\text { Speaking and listening: students } \\
\text { should gain, evaluate, and present } \\
\text { increasingly complex } \\
\text { information, ideas, and evidence } \\
\text { through listening and speaking as } \\
\text { well as through media. Students }\end{array}$ & $\begin{array}{l}\text { Students plan an interview and } \\
\text { prepare questions for sources, } \\
\text { conduct interviews, listen and take } \\
\text { notes/record ideas, and respond to } \\
\text { source information with discussion. }\end{array}$ \\
\hline
\end{tabular}




\begin{tabular}{|l|l|}
\hline $\begin{array}{l}\text { should collaborate to answer } \\
\text { questions, build understanding, } \\
\text { and solve problems. }\end{array}$ & $\begin{array}{l}\text { Example: Student reporter and his } \\
\text { team plan and prepare questions for } \\
\text { the school superintendent about the } \\
\text { budget cuts to fine arts. They set a } \\
\text { meeting with the superintendent, } \\
\text { conduct the interview as a } \\
\text { professional reporter might, ask } \\
\text { questions, record notes, and engage } \\
\text { in conversation about the issue to } \\
\text { question and build understanding of } \\
\text { the circumstances surrounding the } \\
\text { cuts. }\end{array}$ \\
\hline $\begin{array}{l}\text { Language: Students should grow } \\
\text { their vocabularies and appreciate } \\
\text { the nuances of words, and } \\
\text { steadily expand their repertoire of } \\
\text { words and phrases. }\end{array}$ & $\begin{array}{l}\text { Students practice revision and } \\
\text { editing skills as they produce print, } \\
\text { broadcast, and social media } \\
\text { reporting. } \\
\text { Example: Student editors copy edit } \\
\text { and work with reporters to improve } \\
\text { final drafts. They work on language } \\
\text { choices and expression; correctness } \\
\text { of grammar, spelling, and } \\
\text { mechanics; and use of Associated } \\
\text { Press style rules specific to } \\
\text { journalism. }\end{array}$ \\
\hline $\begin{array}{l}\text { Media and technology: Skills } \\
\text { related to media use (both critical } \\
\text { analysis and production of } \\
\text { media) are integrated throughout } \\
\text { the standards. }\end{array}$ & $\begin{array}{l}\text { Students learn a variety of computer } \\
\text { technologies and software in order } \\
\text { to produce quality and professional- } \\
\text { looking media. } \\
\text { Example: Student page designers } \\
\text { plan their page layouts using } \\
\text { particular software for graphics and } \\
\text { design (Adobe Photoshop, } \\
\text { Illustrator, and InDesign). }\end{array}$ \\
\hline
\end{tabular}

Figure 1:

Comparisons of Core and Journalism Practices. 
As we examine the kinds of literacies taught and valued at school, and reevaluate what literacy means and what it should look like in this $21^{\text {st }}$ century, schools will "realize the importance scholastic journalism should still have in today's school curricula" (Konkle 2009:22). Notably, journalism students perform literacies better than peers who do not participate in school media; journalism students earn better grades, achieve higher ACT scores, and earn better grades as college freshmen (Dvorak 2008, Dvorak, Lain, and Dickson 1994).

\section{SIGNIFICANT HISTORICAL MOVEMENTS WITHIN HIGH SCHOOL JOURNALISM}

Even in this era of challenge and change for schools, journalism programs remain significantly connected within the curriculum of English language arts. For purposes of this paper, I briefly discuss three key historical movements that impact scholastic journalism as it relates to its inclusion in ELA: legal battles waged over student expression, technologies that modernized classroom processes, and educational reform as framed by the Common Core.

\section{A. History: Battles Waged Over Student Expression}

Three legal cases directly shape student expression and impact the perceived value of journalism in ELA. In addition to these landmark rulings, nine states (including Iowa) have since passed laws protecting free expression by student journalists (Student Press Law Center 2013). Tinker vs. Des Moines Public Schools (1965) first challenged the limits of student expression when an Iowa school suspended students who wore black armbands to protest the Vietnam War. The U.S. Supreme Court 
ruled against the school and opened new freedoms for student speech, as long as the expression did not substantially disrupt school operations (Reque, Hathaway Tantillo, Babb, McIntosh, and Denham 2001). In 1988, a case from a Missouri high school reversed the progress of students' speech rights. A Hazelwood, Mo. principal censored students reports about divorce and teen pregnancy, describing the wrting as inappropriate for school audiences.

In Hazelwood v. Kuhlmeier, the court ruled in favor of the administrator. Hazelwood did not recognize its school newspaper as a public forum and the case gave administrators the right to prior review. Because of this ruling, today's advisers and staffs may yet feel nervous about approaching reports of controversial content as they may fear school repercussions (Reque, Hathaway Tantillo, Babb, McIntosh, \& Denham 2001, Student Press Law Center 2013). A third case shaping scholastic journalism occurred in 1986 with the school suspension of a student who used sexual innuendo during an assembly speech. The courts upheld the suspension. In Fraser v. Bethel School District, the court determined that schools could control student exposure to 'obscene' language at school. More recent cases of students' arguments with schools about free speech rights - such as Morse V. Frederick (2002) and Doninger v. Niehoff (2007) cases - continue to impact the perceived value of scholastic journalism. The cases highlight continued tensions among students, advisers, and school administrators (Student Press Law Center 2013).

Not all school administrators, faculty, or ELA departments are comfortable with the practices of the journalism classroom (Anderson 2011, Graff 2003, Hall 1984, Haynes-Moore 2011, Hollbrook 1986, Konkle 2010, Murray 2008). Curricular goals of the journalism classroom can be at 
odds with the school-sponsored activities of ELA classrooms in which teachers orchestrate the learning of their classrooms with clearer limitations of student expression. The curricular controls and teaching practices one might anticipate in an ELA classroom don't neatly align with the philosophies and best practices of a scholastic journalism classroom. Scholastic journalism is the ornery sibling of the ELA family tree.

\section{B. History: Influences of technology}

A second historical influence on scholastic journalism is the influence of emergent technologies. Until about the mid 1980 s, journalism students pounded their stories using typewriters. They scaled photos using proportion wheels, created layouts with $\mathrm{X}$-acto knives and grid paper, and decorated pages using line tapes. Students cut and pasted stories onto page grids to prepare camera-ready pages. Some ranks of journalism advisers and student alumni may well remember their fingers burning from the hot wax used to affix stories to page layouts (Pell 2012). Computer technologies significantly impacted publications. Computers, word processing, design software, and desktop publishing influenced the processes of reporters, photographers, and designers who composed their school publication (Brasler and Aimone 2000, Koziol 1981). In the 1980s, computer layouts could produce more sophisticated-looking publications through desktop publishing and by the 1990s students were taking advantage of color, graphics, modern packaging, and modular design (Brasler and Aimone 2000, Cuban 1993, Harrower 2002, Knight 1981). Most recently, demonstrated by the tumult of the print industry, the advent of mobile technology, tablets, and social media significantly shape publication processes and products (Pew 2012). 
With this explosion of $21^{\text {st }}$ century digital tools there is an affordance for journalism students for creativity and innovation. Digital technologies bring revolutionary benefits to teaching and learning (Gee and Haynes 2011, Lankshear and Knobel 2006). Students can access more information and more quickly to better inform, entertain, and build forums of engagement (Digital Media Resources 2013, Dvorak 1994, Halverson and Shapiro 2012, Ito et al. 2008, Jenkins, Purushotma, Clinton, Weigel, and Robison 2007). However, this rapid era of technology also makes it tricky for scholastic journalism programs to meet school expectations (Pell 2012). Some schools may be uninterested or unable to support new technologies (Dvorak 1994, Konkle 2010) and online communications can pose challenges for school officials to monitor and control the dissemination of information (HaynesMoore 2011a). Such digital technologies complicate what and how students report.

\section{History: Reimagining literacy}

A third historical movement directly affects how scholastic journalism is embraced in ELA. We are in the midst of educational reform, particularly with new udnerstandings of what it means to be literate for workplace and society (Gee and Haynes 2011, Hull and Moje 2012, Ito et al. 2008).

Common Core literacies connect with scholastic journalism in that they are cross-curricular and ask students to demonstrate literacies in English, social sciences, science, and technical subjects (Common Core, 2012). Students must learn effective writing, which includes writing with digital technologies (DeVoss, et al. 2010, Journalism Education Association 2013, National Council of Teachers of English, 2012). 
Differing perspectives of scholars and classroom educators fuel discussions about what reading and writing practices "should" look like in English classrooms; these debates impact society's understanding of literacy as a flexible and evolving process of communication (Herrington, Hodgson, \& Morgan, 2009; Luke, Freebody, and Land 2000). School literacies are shared practices that involve human language, including productions of images, audio, video, graphics, and multimedia (Gee and Hayes 2011; Herrington, Hodgson, and Moran 2009, Hull and Moje 2010). This shift in thinking about what it literacy means, and how schools might achieve literacy goals with students, holds great potential for the recognition of journalism as a vital coursework in English language arts.

\section{ROOTS OF ENGLISH ELECTIVES IN THE HIGH SCHOOL CURRICULUM}

School publications have not always been considered significant. Programs emerged in the 1890 s as popular afterschool literary societies in which students congregated to share their writing. These groups would publish a magazine, book of poetry, or yearbook, and gradually these activities became part of school curriculum (Applebee 1974, Jaekle 1972, Konkle 2009, Hill and Snyder 1930, Logan 1965, Murphy 1974). English curriculum in the 1890s focused on spelling, grammar, rhetoric, and composition (Christenbury 1979, Smith, Strong, Guthe, and Bemis 1899). In 1892, the Committee of Ten encouraged schools to treat English as a serious study and in 1912 the NCTE and its English Journal elevated English as a worthy endeavor (Applebee 1974). English departments of the 1960s restructured to include electives such as drama, debate, and journalism (Christenbury 1979, Palmatier and Martin, 
144 Celt, Volume 13, Number 2, December 2013:133-154

1976, Santora 1979), though such electives were sometimes a “dumping ground" for low-level students (Olman 1993).

English teachers developed journalism programs by taking cues from the professional press. Students' work mimicked the design and reporting of city papers (Brasler and Aimone 2010, Harrower 2002, Knight 1981). Social and political unrest motivated students to write about the Vietnam War, drugs, sex, racial problems, and family problems. Students discovered a power in writing, and this attracted new participants as students sought to express themselves and add their voices to the community (Knight 1981). Enrollment increased. Programs gained recognition for cutting-edge research, writing, and design (Brasler and Aimone 2010, Logan 1965). Journalism educators documented the ways students engaged in meaningful and relevant learning (Dvorak 1985, Hall 1984). In 1984, the National Council of Teachers of English passed a resolution to officially accept journalism courses focused on the collecting, writing, editing, interpretation and evaluation of information (Holbrook 1986). This affirmed journalism as a worthy course placed in English curriculum. Today's scholastic journalism programs add podcasts, blogs, broadcasts and social media into their curriculum (Digital Media Resources 2013, Dvorak 2002, Goodman, Bowen, and Bobkowski 2011).

\section{IMPLICATIONS FOR CLASSROOM PRACTICES}

I suggest six actions to strengthen and reinforce the value of scholastic journalism as related to the teaching and learning of English language arts.

1. Teach writing. New technologies will emerge, schools will introduce new standards, and employers will discover yet-to- 
be-imagined $21^{\text {st }}$ century jobs. Being able to write well will weather such changes. Writing with purpose, voice, clarity, and evidence is an essential skill. Writing in journalism is an experience of producing a product for an authentic audience. Student writing reflects an ability to organize ideas, use multiple resources of information, think critically, collaborate, revise, and edit language.

2. Get certified. One hopes that journalism advisers would pursue training and advanced learning through local, regional, and national workshops. Many grants are available for development. Veteran advisers are eager for younger or newer colleagues to take advantage of these opportunities. We know our classroom instruction and student learning improves from highly qualified teachers. We must be knowledgeable of current media practices, technologies, laws, and instructional methods to help our programs maintain credibility with our ELA department, school, district, and community. Advisers should be certified and be able to promote the values and needs of the program. Our ELA colleagues must be certified to teach speech and drama electives; why is the journalism adviser not also highly qualified?

3. Build relationships. Seek connections between your student programs and professional media. Invite television, radio, newspapers, magazines, photographers, advertising agencies, and social media producers to visit with students, study products, and discuss technique. These professionals reinforce the high expectations of literacy needs in the workplace. They also bring relevance to scholastic journalism. Area media are vocal supporters of First Amendment rights and these professionals can speak about these issues with students, principals, parents, and school boards. Call upon these professionals to help teach technology and media trends; it can 
be overwhelming to keep up with the changing world of journalism when there is more to one's teaching job than the journalism elective. Nurturing community connections will bring positive, public attention to the school and the networking may open opportunities for student job shadows, internships, and jobs.

4. Communicate success. Newspapers are only a format; journalism is not dying, in fact, the need for our students to be sharp critical thinkers who are able to express themselves in a multiplicity of ways is crucial. There may exist misconceptions about what journalism is and what it means for today's students. Advisers must illustrate to their administration and colleagues that their students are practicing and learning valuable literacy skills. Align students' work with NCTE and IRA standards. Produce a school video or speak to the PTA about how the Common Core plays out when students engage in research and writing. Advisers know that learning occurs in the midst of the chaos of the journalism classroom. Seek to show how the learning experiences of journalism are at minimum comparable to, if not better than, traditional ELA classrooms.

5. Secure technology. Schools that say they embrace journalism as a healthy member of their ELA family should treat the program as such; this means that advisers must be vocal about the program needs and not shy asking for materials and technology upgrades. If we aim to reach $21^{\text {st }}$ century learning expectations, we should expect that $21^{\text {st }}$ learning tools are available to help us get our students there.

6. Recruit diverse learners. Journalism classrooms are energyfilled spaces that should attract students of any gender, race, class, ethnicity, or culture. Diversity of people on staff enriches learning as students socialize and collaborate. Journalism 
students today are also not only writers, but photographers, videographers, social media junkies, YouTube aficionados, and graphic arts specialists. Advisers might find staff members from art, speech, theatre, web, or business classes. Watch for students who may practice these literacies outside of the school day, too. Diversity of participants and stronger registration numbers adds support for the journalism elective as an important component of $21^{\text {st }}$ century curriculum.

\section{CONCLUDING REMARKS: MOVING SCHOLASTIC JOURNALISM FORWARD}

Scholastic journalism is in sea change learning to effectively approach and teach literacies. This movement is not unlike those of past decades in which English language arts teachers hotly debated what students should know, learn, and be able to demonstrate. Healthy skepticism and speculation about changing communications impact our ways of thinking about literacy. Evolution of technologies continues to add new twists to wondering about adapting our program curriculum in relevant and meaningful ways. Scholastic journalism must adapt -- and quickly - as our history as an elective in ELA reminds us that we must not be complacent.

\section{REFERENCES}

Applebee, A. Tradition and reform in the teaching of English: A history. Urbana, IL. Retrieved from http://www.ncte.org/ library/NCTEFiles/Centennial/Tradition-Reform.pdf, 1974.

Anderson, A. "High school journalism classes threatened in Florida". In Poynter Online. Retrieved from http://www.poynter. org/uncategorized/92163/high-school-journalism-classesthreatened-in-florida/, 11 April 2011. 
148 Celt, Volume 13, Number 2, December 2013:133-154

Brasler, W. and L. Aimone. "The saga of the high school press". In NSPA Newspaper Guide Book. Retrieved from http:// www.studentpress.org/nspa/pdf/wheel_history-of-scho lasticnewspapers.pdf, 2010.

Chavanu, B. and L. Christenbury, L. "Electives: once more to the defense". In English Journal, Vol. 89, No. 6, 2000: 22-26. doi: $10.2307 / 821257$

Christenbury, L. "The secondary English elective curriculum". In English Journal, Vol. 68, No. 6, 1979: 50-54. doi: $10.2307 / 815924$

Christenbury, L. "An untimely death: an elegy for the elective curriculum". In National Council of Teachers of English, Vol. 83, No. 3, 1994:18-22. doi:10.2307/820922

Clayton, A. (1998). "Emerging technology and the $21^{\text {st }}$ century". In Scholastic journalism in the $21^{\text {st }}$ century: A report on the future of scholastic journalism from the CSPAA, retrieved from http://cspa.columbia.edu/docs/advisersassociation/21stCenturyReport/index.html, 1998.

Columbia Scholastic Press Association. Scholastic journalism in the $21^{\text {st }}$ century: A report on the future of scholastic journalism from the CSPAA, retrieved from http://cspa.columbia. edu/docs/advisers-association/21 stCenturyReport/index.html, 1998.

Common Core State Standards Initiative.Implementing the common core state standards. Retrieved from http://www.core standards.org/, 2012

Cuban, L. "Computer meets the classroom: the classroom wins". In Teachers College Record, Vol. 95, No. 2, 1993:185-210. Retrieved from http://www.tcrecord.org

DeVoss, Eidman-Adahl and Hicks. Because digital writing matters: Improving student writing in online and multimedia environments. San Francisco, CA: Jossey-Bass, 2010. 
"Digital Media Resources". Retrieved from http://www.jea digitalmedia.org/, 2013

Downes, M.K., B. Hayes, K. Furnas,and M. Newton. "Standards for journalism educators". Retrieved from http://jea.org/home/foreducators/standards, 2012.

Dvorak, J.“Journalism's Role in the secondary school language arts curriculum in the context of the educational reform movement". A paper presented at the Mid-Winter Meeting of the Secondary Education Division of the Association for Education in Journalism and Mass Communication, Indianapolis, IN. Retrieved from ERIC database. (ED253879), 1985.

Dvorak, J. "Status of journalism and news media in the nation's secondary schools". Indiana University. Retrieved from http://journalism.indiana.edu/programs/hsji/high-schoolresearch/status-of-journalism-and-news-media-in-the-nationssecondary-schools/, 1998.

Dvorak, J. "High school electronic journalism survey. Radio and Television News Directors Association" Retrieved from http://journalism.indiana.edu/programs/hsji/wp-content/up loads/wp_programs_hsji_File/HSJI.pdf, 2002.

Dvorak, J. High school journalism matters: Journalism student academic performance in the $21^{s t}$ century. In Newspaper Association of America Foundation. A presentation retrieved from http://www.americanpressinstitute.org/docs/Foundation/ Resources/Conference/2008/sessions_dvorak.pdf, 17 May 2008

Dvorak, J., T. Lain, and T. Dickson. "Journalism Kids Do Better: What research tells us about high school journalism". Bloomington, IN, 1994.

The Freedom Forum. "Death by cheeseburger: High school journalism in the 1990s and Beyond". Retrieved from 
150 Celt, Volume 13, Number 2, December 2013:133-154

http://archive.firstamendmentcenter.org/pdf/dbc_text.pdf, February 1994.

Gee, J. andE. Hayes. Language and learning in the digital age. London: Routledge, 2011.

Goodman, M., C. Bowen, and P.Bobkowski."Student media presence remains strong in American public high schools". Kent, Ohio: Kent State University, Center for Scholastic Journalism. Retrieved from http://jnewsdesk.weebly.com/uploads/3/8/ 0/0/380078/csj_census_2011.pdf, 2011.

Graff, P."Standards in the journalism classroom". In State of scholastic journalism:Principal's guide to Scholastic Journalism. Quill and Scroll Foundation: University of Iowa, 2003.

Hall, H.L. "Will scholastic journalism survive?" In Communication: Journalism Education Today, Vol. 17, No. 4, 1994:2-3. Retrieved from ERIC database. (ED297959).

Halverson, R. and R.B. Shapiro. "Technologies for Education and Technologies for Learners: How Information Technologies Are (and Should Be) Changing Schools (WCER Working Paper No. 2012-6)". Retrieved from http://www.wcer.wisc. edu/publications/workingPapers/Working_Paper_No_2012_06 .pdf, 2012.

Harrower, T. The newspaper designer's handbook. $\left(5^{\text {th }}\right.$ ed.) New York, NY: McGraw-Hill, 2002.

Hill, C. and G. Snyder."Curricular and extra-curriculum possibilities of journalism in secondary schools". In The School Review, Vol. 38, No. 8, 1930:585-597. doi: 10.1086/439070.

Haynes-Moore, S. "Tensions in school: Social media". In Quill and Scroll. Retrieved from http://issuu.com/quillscroll/docs/ quillscrollmagspring2011, Spring 2011.

Haynes-Moore, S. "Creating a space in school for social media". A paper presented at the 2011 Literacy Research Association 
conference. Retrieved from ftp://conflibs.Literacyresearch association.org/61st_Annual_Mtg/HMoore_symposiumLRA2 011.pdf, December 2011.

Hollbrook, H."Journalism in the English classroom. In English Journal, Vol. 75, No. 7, 1986:70-72. doi: 10.2307/818507

Hull, G. and E. Moje."What is the development of literacy the development of?"A paper presented at the Understanding Language Conference at Stanford University, California, retrieved from http://ell.stanford.edu/sites/default/files/pdf/ academic-papers/05-Hull $\% 20 \% 26 \% 20 \mathrm{Moje} \% 20 \mathrm{CC} \% 20$ Paper\%20FINAL.pdf, 2012.

Ito, M., H. Horst, M. Bittani, D. Boyd, B. Herr-Stephenson, P. Lange, and L. Robinson. "Living and Learning with New Media: Summary of Findings from the Digital Youth Project". Macarthur Foundation Digital Media and Learning Project. Retrieved from http://digitalyouth.ischool.berkeley.edu /files/report/digitalyouth-WhitePaper.pdf, November 2008.

Jaekle, A. "Spontaneity with a purpose: elective English programs". In English Journal, Vol. 61, No. 4, 1972:529-535. doi: $10.2307 / 813564$

Jenkins, H., R. Purushotma, K. Clinton, M. Weigel, and A. Robison, 'Confronting the challenges of participatory culture: Media education for the $21^{\text {st }}$ century". MacArthur Foundation Digital Media and Learning White Paper Series. Retrieved from http://newmedialiteracies.org/files/working/NMLWhitePaper.p df, 2007.

Journalism Education Association.Retrieved from http:/www.jea. org, 2013.

Knight, R. "Scholastic journalism comes of age". School Press Review, Vol. 57, No. 4, 1981:8-12.

Konkle, B. "The English and journalism secondary education curriculum connection: A preliminary historical perspective". 
152 Celt, Volume 13, Number 2, December 2013:133-154

A paper presented at the meeting of Association for Education in Journalism and Mass Communication, San Francisco, CA. Retrieved from http://www.jour.sc.edu/people/adfacstaff/pdfs/ Konkle_research/English-Journalism\%20connection\%20'06. pdf, 2006.

Konkle, B. "Scholastic journalism's connection to other high school curriculum".A paper presented at the meeting of Association for Education in Journalism and Mass Communication, St. Petersburg, FL., Retrieved from http://jour.sc.edu/people/adfac staff/pdfs/Konkle_research/Scholastic\%20journalism's\%20con nection\%20'08.pdf, 2008.

Konkle, B. "Scholastic Journalism's Value to Secondary Schools, According to Past Curriculum and Education History Textbook Authors".A paper presented at the meeting of Association for Education in Journalism and Mass Communication, St. Petersburg, FL., Retrieved from http://www.jour.sc.edu/people/adfacstaff/pdfs/Konkle_researc h/Value\%20of\%20scholastic\%20journalism\%20'09.pdf, 2009.

Konkle, B. "School administrators' perceptions of scholastic journalism during the 20th Century".A paper presented at the meeting of Association for Education in Journalism and Mass Communication, St. Petersburg, FL., Retrieved from http://jour.sc.edu/people/adfacstaff/pdfs/Konkle_research/Scho lastic\%20journalism's\%20connection\%20'08.pdf, 2010.

Koziol, R."Future trends in journalism education". In School Press Review, Vol. 56, No. 7, 1981:12-13. Retrieved from ERIC database. (EJ242144).

Lankshear, C. and M. Knobel. New literacies: Everyday practices and classroom learning, $2^{\text {nd }}$ ed. New York, NY:Open University Press, 2006.

Logan, E. "Journalism: a wide open field". In English Journal, Vol. 54, No. 7, 1965:623-625. doi: 10.2307/811269 
Luke, A., A. Woods and K. Weir. (2013). Curriculum, syllabus design and equity, a primer and model. New York, NY: Routledge, 2013.

Moss, A. "Introducing literary journalism into the curriculum". Presentation at the Journalism Education Association national convention in St. Louis, MO, 13 October 2008.

Murphy, J. "History of school press". In School Press Review.Vol. 48, No. 8, 1974:19-21. Retrieved from ERIC database. (EJ095955).

Murray, M.“I didn't always think well of the student press". In The School Administrator, Vol. 3, No. 65. Retrieved from http://www.splc.org/pdf/aasafreepressarticle2.pdf, 2008.

National Council of Teachers of English. Standards for the English Language Arts. National Council of Teachers of English \& International Reading Association. Urbana, IL: NCTE. Retrieved from http://www.ncte.org/standards/ncte-ira, 2012.

National Council of Teachers of English. Resolution on the importance of journalism courses and programs in English curricula. National Council of Teachers of English \& International Reading Association. Urbana, IL: NCTE. Retrieved from http://www.ncte.org/positions/statements/journalismincurr, 2012.

Olman, G. "Journalism courses often a dumping ground in high school curricula". In Editor \& Publisher, Vol. 126, No. 29, 1993:56.

Palmatier, L. and M. Marti."Ten guidelines for establishing an elective program". In English Journal. Vol. 65, No. 4, 1976:28-31. doi: 10.2307/815178

Pell, C. "On being tired, but mostly inspired". In Scholastic Source Newsletter. AEJMC scholastic journalism division: Scholastic source. Retrieved from http://aejmc.net/scholastic/wp- 
154 Celt, Volume 13, Number 2, December 2013:133-154

content/uploads/2012/12/SJD_SourceDec12email1.pdf, Winter 2012.

The Pew Research Center. "Project for excellence in journalism: The state of the news media 2012". Retrieved from http://stateofthemedia.org/, 2012.

Reque, J., S. Hathaway Tantillo, J. Babb, M. McIntosh and B. Denham, B. Introduction to Journalism. McDougal Littell, 2001.

Santora, R. "Recent trends in the teaching of literature". In English Journal. Vol. 68, No. 6, 1979:38-42. doi: 10.2307/815922

Smith, W., E. Strong, K. Guthe, C. Bemis. "Elective work in the high school courses, should elective work be provided and encouraged?" InThe School Review, Vol. 7, No. 4, 1899:232245. Chicago, IL: University of Chicago School of Education. Retrieved from http://books.google.com/

Student Press Law Center. "Know your rights". Retrieved from http://www.splc.org/knowyourrights/, 2010. 